\title{
UPAYA MENINGKATKAN PEMAHAMAN SISWA DALAM PEMBELAJARAN MATEMATIKA MELALUI PENERAPAN PENDEKATAN KONSTRUKTIVISME
}

\author{
Triwahyu Riyatuljannah \\ Sekolah Dasar Islam Terpadu Adzkia 3, Kota Sukabumi, Jawa Barat, Indonesia \\ triwahyuriatuljanah@gmail.com
}

Naskah diterima: tanggal 5 September 2018, direvisi: tanggal 11 September 2018, diterbitkan: tanggal 31 Oktober 2018

\begin{abstract}
This study aims to improve students' understanding on each cycles, and to determine the activities of students and teachers in each cycles activities towards learning mathematics by using constructivism approach. This research uses classroom action research, which is the subject of this research is the students of grade $V$ of Madrasah Ibtidaiyah Negeri (MIN) 1 Bandung City amounting to 43 students consisting of 21 male students and 22 female students. This research instrument consists of students' mathematical description and observation sheet of teacher activity and student activity. Based on data analysis of research results there is increasing understanding of students ranging from pre cycles of $39.5 \%$, the first cycle of $81.3 \%$ and the second cycle of $97.6 \%$ with very good criteria. In addition, the student activity also increased in each cycle, in the first cycle of $68.7 \%$ and the second cycle of $95.8 \%$ and teacher activity that increased from cycle I of $83.3 \%$ and cycle II reached the maximum score of $100 \%$. The attitude of learners to the learning of mathematics with constructivism approach is very enthusiastic because it has a positive response, score obtained by students exceeds the average score.
\end{abstract}

Keywords: constructivism approach, matemathic, cognitive skill

\begin{abstract}
ABSTRAK
Penelitian ini bertujuan untuk meningkatkan kemampuan pemahaman siswa pada setiap siklusnya, dan untuk mengetahui aktivitas siswa serta aktivitas guru setiap siklusnya terhadap pembelajaran matematika dengan menggunakan pendekatan konstruktivisme. Penelitian ini menggunakan metode penelitian tindakan kelas (classroom action research) dan pendekatan mixed methods, yang menjadi subjek penelitian ini adalah siswa kelas V MI Negeri 1 Kota Bandung berjumlah 43 siswa yang terdiri dari 21 orang siswa laki-laki dan 22 orang siswa perempuan. Instrumen penelitian in terdiri dari soal uraian matematika siswa dan lembar observasi aktivitas guru dan aktivitas siswa. Berdasarkan analisis data hasil penelitian terdapat peningkatan pemahaman siswa mulai dari pra siklus sebesar $39,5 \%$, siklus I sebesar $81,3 \%$ dan siklus II sebesar $97,6 \%$ dengan kriteria sangat baik. Selain itu aktivitas siswa juga mengalami peningkatan pada setiap siklusnya, pada siklus I sebesar $68,7 \%$ dan siklus II sebesar 95,8\% serta aktivitas guru yang mengalami peningkatan dimulai dari siklus I sebesar $83,3 \%$ dan siklus II mencapai skor maksimal yaitu sebesar $100 \%$. Sikap peserta didik terhadap pembelajaran matematika dengan pendekatan konstruktivisme sangat antusias sebab memiliki respon positif, skor nilai yang diperoleh siswa melebihi skor nilai rata-rata.
\end{abstract}

Kata Kunci: pendekatan kontruktivisme, pembelajaran Matematika, pemahaman

\section{PENDAHULUAN}

Guru merupakan salah satu komponen utama dalam pendidikan. Keberadaan dan peran guru amat menentukan keberhasilan pendidikan. Untuk meningkatkan kemampuan profesionalnya guru senantiasa berupaya meningkatkan pengetahuan dan keterampilan 
profesionalnya melalui pendidikan dan pelatihan. Realita pendidikan di Indonesia pada umumnya dalam kegiatan pembelajaran yang ada di SD/MI masih cenderung bersifat konvensional dan pembelajarannya masih didominasi oleh guru dan sedikit melibatkan siswa. Sehingga peserta didik mengalami kesulitan belajar yang dapat menyebabkan prestasi yang diperoleh rendah diantaranya pada pelajaran matematika.

Pelajaran matematika memiliki peran penting untuk menciptakan pola berpikir siswa yang runtut. Mengingat bahwa pentingnya peran pembelajaran matematika, pendidik sebaiknya harus mampu menguasai bagaimana sistem pendidikan berlangsung dan mengajarkan cara siswa belajar agar tercapainya pembelajaran yang maksimal (Husni, 2012). Sesuai dengan pernyataan (Setyawan dan Rahman, 2013), bahwa matematika Matematika adalah hal yang penting maka siswa harus paham dengan apa yang telah diketahui mengenai matematika. Faktanya, pemahaman siswa pada konsep matematika masih kurang. Kurangnya siswa dalam memahami konsep matematika karena kerumitan rumus dan simbol, selain itu karena kegiatan belajar yang nampak berdasarkan teori serta tidak berhubungan dengan lingkungannya.

Siswa akan paham dengan pembelajaran matematika bila aktif dalam membentuk pengertian serta pemahaman pada inderanya berupa penglihatan dan lainnya. Pengertian yang dipunyai siswa sudah bentukannya sendiri melalui interaksi lingkungan, konstruktivisme merupakan salah satu pendekatan yang dapat mengkonstruk pengetahuan dan pemahamannya lebih dalam tentang matematika.

Konstruktivisme menurut istilah adalah sebuah pengetahuan yang telah diketahui berdasarkan apa yang telah dialami. Konstruktivisme berarti manusia membangun sendiri pemahaman dan pengetahuan dari apa yang telah didapat dan mengevaluasinya. Konstruktivisme merupakan teori bahwa kegiatan pembeajaran ialah kegiatan sendiri. Piaget dalam (Bhattacharjee, 2015) dengan teori konstruktivisnya sejalan dengan Jayeeta, menyatakan bahwa setiap siswa membawa pengertian dan pengetahuan pertama yang sudah dipunyai ke dalam kegiatan belajarnya harus ditambah, dimodif, perbarui, revisi, dan berubah pada informasi yang ditemui dalam kegiatan belajar. (Dwijayanti, 2014).

Seperti yang diungkapkan oleh Diaz (2017) bahwa "Constructivism is a learning theory that describe the process of knowledge construction. the construction of knowledge is an active process, not passive. in the field of mathematics, this is because a mathematical learning based on constructivist theory provides the knowledge that is not only stored in the minds of students, but also actively building new knowledge from experience and knowledge. Effective learning of mathematics requires that students understand what they know and need to learn, and this motivation will help them learn more."

Siswa belajar melalui proses adaptasi terhadap lingkungan yang melibatkan asimilasi dan akomodasi. Asimilasi merupakan proses bergabungnya stimulus kedalam struktur kognitif. Sedangkan akomodasi adalah berubahnya pemahaman sebagai hasil dari stimulus yang diperoleh. Siswa yang berinteraksi dengan lingkungan kemudian merespon berbagai stimulus, stimulus yang diterima oleh siswa akan menjadi pengetahuan baru bagi siswa artinya struktur kognitif siswa menjadi meningkat. Sedangkan stimulus yang ditolak tidak akan menjadi pengetahuan bagi siswa dan struktur kognitifnya tidak meningkat.

Menyikapi pentingnya pemahaman siswa terhadap materi pada pembelajaran matematika, maka perlu diadakan perubahan dalam proses pembelajaran dari konvensional ke arah yang dinamis. Pembelajaran yang dinamis yang akan menuntun siswa ke arah keberhasilan dalam belajarnya. Maka diperlukan cara untuk mengatasi permasalahan 
tersebut dengan menggunakan pendekatan yang tepat agar siswa tidak lagi pasif ketika proses pembelajaran berlangsung.

Kegiatan pembelajaran menurut konstriktivisme adalah kegiatan peserta didik untuk membangun pengertian, baik dari tulisan, percakapan, pengalaman dan sebagainya. Kegiatan konstruksi dilaksanakan oleh individual ataupun berkelompok (Retno, 2013:206). Hakikatnya, belajar merupakan proses mengasimilikasikan dan menghubungkan pengalaman yang dipelajari dengan pengetahuannya sendiri. Pendekatan konstruktivisme memandang pelajaran tidak dapat dipindahkan begitu saja dari satu sumber ke sumber lainnya, karena siswa sendiri yang harus mengartikan apa yang diajarkan sesuai pengalaman. Berdasarkan hasil observasi awal yang telah dilakukan di MI Negeri 1 Kota Bandung, masih banyak siswa yang nilai mata pelajaran matematika dibawah rata-rata KKM sebesar 70. Hal ini disebabkan karena tidak sedikit siswa yang diduga mengalami kesulitan dalam memahami konsep pembelajaran matematika seperti pada materi matematika yang diberikan sebelumnya yaitu bangun ruang. Selain itu proses pembelajaran yang dilakukan guru di kelas kurang melibatkan siswa dalam proses pembelajaran. Dalam proses pembelajaran, siswa tidak mengeksplorasi, menemukan sifatsifat, menyusun konjektur kemudian mengujinya tetapi hanya menerima apa yang diberikan oleh guru dan siswa sebagai penerima materi. Pada pembelajaran dengan pendekatan konvensional ini siswa menyelesaikan banyak soal tanpa memahami secara mendalam apa yang telah didapat dari pembelajaran sebelumnya, hal ini dapat mengakibatkan kemampuan penalaran siswa tidak berkembang dengan baik dan prestasi siswa berkurang.

\section{METODOLOGI}

Jenis penelitian ini adalah penelitian tindakan kelas, dilaksanakan pada siswa kelas $\mathrm{V}$ MIN 1 Kota Bandung Tahun Ajaran 2016/2017, sebanyak 43 orang, siswa laki-laki 21 orang dan siswa perempuan 22 orang dan guru. Pokok bahasan dalam penelitian ini adalah "Pengolahan Data". Desain penelitian mengikuti model Hopkins yang dilaksanakan bersiklus (Arikunto, 2009). Setiap siklus meliputi empat tahapan yaitu 1) Perencanaan, 2) Pelaksanaan, 3) Observasi dan 4) Refleksi.

Pendekatan penelitian ini menggunakan pendekatan mixed methods, dimana pada pendekatan ini menggunakan strategi penelitian yang melibatkan pengumpulan data baik secara simpulan maupun secara squensial untuk memahami masalah penelitian sebaikbaiknya. Sehingga pengumpulan data juga melibatkan pemerolehan baik informasi numerik ataupun teks sehingga database akhir mempresentasikan informasi baik kualitatif ataupun kuantitatif (Emzir, 2013). Penggunaan pendekatan mixed methods pada penelitian ini karena dibutuhkannya pengumpulan data baik kualitatif dan kuantitatif, yaitu untuk memperoleh data peningkatan pemahaman matematika siswa melalui kegiatan mengidentifikasi, mendokumentasi dan mengetahui interpretasi siswa secara mendalam yang bisa dilakukan dengan tes tertulis dan observasi selama penelitian berlangsung. Penerapan mixed methdos adalah metoda untuk pengumpulan data dalam rangka memperoleh jawaban tentang masalah yang diteliti. Mixed methods juga menghasilkan fakta yang lebih komprehensif dalam masalah penelitian karena peneliti dapat mengunakan alat pengumpul data yang dibutuhkan.

Metode yang digunakan dalam penelitian ini adalah Penelitian Tindakan Kelas (Classroom Action Research). Menurut Hopkins (Wiriatmaja, 2012) Penelitian tindakan kelas adalah untuk mengidentifikasi kelas yang dikombinasikan dengan prosedur penelitian dengan tindakan sunbstantif atau sebuah tindakan yang dilakukan mengunakan 
inkuiri atau usaha seseorang yang terlibat dalam sebuah proses pembelajaran untuk lebih memahami agar timbulnya perbaikan dan perubahan. Seperti pendapat Hopkins, bahwa tujuan penelitian tindakan kelas ini adalah untuk memperbaiki dan meningkatkan kualitas pembelajaran matematika siswa serta membantu memberdayakan guru dalam memecahkan masalah.

Jenis data yang dikumpulkan dalam penelitian ini adalah data kualitatif dan kuantitatif. Data kualitatif merupakan data yang diperoleh dari deskripsi lembar observasi yang digunakan untuk memberikan gambaran proses pembelajaran matematika melalui penerapan pendekatan konstruktivisme kelas V MIN 1 Kota Bandung yang meliputi aktvitas guru dan siswa. Sedangkan data kuantitatif adalah data yang berupa angka-angka dan bertujuan untuk memperoleh informasi mengenai data tentang penerapan pendekatan konstruktivisme pembelajaran matematika yaitu melalui hasil tes matematika dan format observasi.

Alat pengumpulan data yang digunakan dalam penelitian ini adalah kuantitatif dan kualitatif. Data kuantitatif adalah data yang berupa angka atau bilangan berupa tes setiap siklus dan data kualitatif adalah lembar observasi. Teknik pengumpulan data ini berupa:

\section{Observasi}

Observasi adalah teknik pengumpulan data yang memiliki ciri spesifik bila dibandingkan dengan teknik lain. Menurut Sutrisno (Triyono, 2013: 157-158), observasi adalah cara pengumpulan data yang cara kerjanya dengan melakukan pengamatan dan pencatatan observer secara terstruktur terhadap objek yang diteliti atau diamati baik dalam kondisi khusus di dalam laboratorium maupun kondisi alamiah. Sebagai contoh, penelitian yang tersusun dalam beberapa siklus dan setiap siklusnya terdiri dari tahapan perencanaan tindakan, pelaksanaan tindakan, pengamatan tindakan, pengamatan tindakan, refleksi dan evaluasi hasil tindakan.

Observasi dilaksanakan di MIN 1 Kota Bandung, alat yang digunakan berupa lembar observasi. Lembar observasi digunakan untuk mengamati aktivitas siswa dan aktivitas guru selama proses pembelajaran matematika yang telah disusun berdasarkan RPP.

2. Tes

Tes merupakan suatu alat penilaian dalam bentuk tulisan untuk mencatat atau mengamati prestasi siswa yang sejalan dengan target penilaian (Jacobs \& Chase, 1992.) Jawaban dari tes biasanya berupa tes tertulis, lisan maupun perbuatan. Zainal dan Nasution (2001) mengungkapkan tes adalah bentuk pertanyaan atau tugas yang dirancang untuk mendapatkan informasi mengenai perangkat pendidikan atau perangkat psikologis tertentu. Setiap butir pertanyaan atau tugas memiliki jawaban atau ketentuan yang dianggap benar. Maka, apabila suatu pertanyaan menuntut harus dikerjakan oleh seseorang, tetapi tidak ada jawaban atau cara pengerjaan yang benar dan slah maka tugas atau pertanyaan tersebut bukanlah tes. (Abdul dan Aep, 2014: 41)

Tes yang digunakan dalam penelitian ini adalah berupa LKS (Lembar Kerja Siswa) yang berbentuk soal uraian yang akan dikerjakan oleh siswa pada setiap akhir siklus dan penilaiannya menggunaakan penilaian rubrik. Tes soal uraian disusun berdasarkan indikator pemahaman.

Analisis data pada penelitian ini mengggunakan observasi dan tes. Teknik pengumpulan data menggunakan observasi ini digunakan untuk mengetahui penerapan pendekatan konstrukivisme pada pembelajaran matematika. Data diambil dari hasil observasi aktivitas guru dan siswa, pengalaman aktivitas guru dan siswa akan dilakukan 
pada setiap siklus pembelajaran matematika. Data yang diperoleh dari hasil observasi aktivitas guru dan siswa akan dianalisa dengan menggunakan skor di setiap siklus yang terjadi dengan ketentuan skor.

Skor aktivitas guru : Persentase $=\frac{\text { Skor hasil observasi }}{\text { Skor total }} \times 100 \%$

Tabel 1 Interpretasi Keterlaksanaan Guru

\begin{tabular}{|c|c|c|}
\hline Persentase $(\%)$ & Bobot & Kategori \\
\hline $86-10 \mathrm{~s} 0$ & 4 & Sangat Baik \\
\hline $76-85$ & 3 & Baik \\
\hline $60-75$ & 2 & Cukup \\
\hline $55-59$ & 1 & Kurang \\
\hline$\leq 54$ & - & Sangat Kurang \\
\hline
\end{tabular}

(Gupita, 2016)

Skor aktivitas siswa : Persentase $=\frac{\text { Skor hasil observasi }}{\text { Skor total }} \times 100 \%$

Tabel 2 Kriteria Penilaian

\begin{tabular}{|c|c|c|c|}
\hline 1 & 2 & 3 & 4 \\
\hline $\begin{array}{c}\text { Tidak ada siswa } \\
\text { yang melakukan } \\
\text { aktivitas }\end{array}$ & $\begin{array}{c}\text { Sebagian siswa } \\
\text { melakukan aktivitas }\end{array}$ & $\begin{array}{c}\text { Hampir semua siswa } \\
\text { melaukan aktivitas }\end{array}$ & $\begin{array}{c}\text { Semua } \\
\text { siswamelakukan } \\
\text { aktivitas }\end{array}$ \\
\hline
\end{tabular}

(Gupita, 2016)

Tabel 3 Interpretasi Keterlaksanaan Siswa

\begin{tabular}{|c|c|}
\hline Persentase & Kategori \\
\hline $80 \%-100 \%$ & Baik Sekali \\
\hline $70 \%-79 \%$ & Baik \\
\hline $60 \%-69 \%$ & Cukup \\
\hline$>50 \%$ & Kurang \\
\hline
\end{tabular}

(Gupita, 2016)

Adapun analisis data siswa menggunakan tes yang meliputi sebagai berikut:

a) Ketuntasan belajar individual

Untuk mengetahui ketuntasan individual yaitu menggunakan rumus.

$$
\text { Nilai }=\frac{\text { Jumlah skor yang dicapai siswa }}{\text { Skor maksimal }} \times 100
$$

b) Ketuntasan belajar klasikal

Ketuntasan belajar klasikal yaitu untuk mengetahui ketuntasan belajar secara keseluruhan. Jika ketuntasan belajar mencapai 85 atau lebih maka siswa secara keseluruhan dinyatakan tuntas belajar. Untuk menghitung ketuntasan belajar secara klasikal yaitu menggunakan rumus:

$$
\text { Rumus }=\frac{\text { Jumlah siswa yang tuntas }}{\text { Jumlah siswa }} \times 100 \%
$$

(Gupita, 2016) 
c) Adapun untuk mengetahui nilai rata-rata pemahaman konsep siswa digunakan rumus.

$\bar{X}=\frac{\sum_{X}}{\sum_{N}}$

Keterangan:

$\bar{X} \quad$ : Nilai rata-rata

$\sum X \quad$ : Jumlah semua nilai siswa

$\sum N \quad$ : Jumlah siswa

Tabel 4 Kriteria Tingkat Ketuntasan Belajar Siswa

\begin{tabular}{|c|c|c|}
\hline No & Tingkat Ketuntasan & Kategori \\
\hline 1 & $80-100$ & Sangat Baik \\
\hline 2 & $70-79$ & Baik \\
\hline 3 & $60-69$ & Cukup \\
\hline 4 & $50-59$ & Kurang \\
\hline 5 & $0-49$ & Gagal \\
\hline
\end{tabular}

(Gupita, 2016)

\section{HASIL DAN DISKUSI}

A. Deskripsi Hasil Evaluasi Belajar

Evaluasi terhadap pembelajaran yang dilakukan kepada 43 orang siswa kelas V MI Negeri 1 Kota Bandung dilakukan pre test sebanyak tiga kali yaitu pada pra siklus, siklus I dan siklus II dengan tujuan untuk mengetahui perkembangan pemahaman siswa terhadap materi yang diajarkan. Ringkasan hasil analisis data pre test ditunjukan pada Tabel 5.

Tabel 5. Ringkasan Hasil Analisis Evaluasi Belajar

\begin{tabular}{|l|c|c|c|}
\hline \multirow{2}{*}{\multicolumn{1}{|c|}{ Aspek Perolehan }} & \multicolumn{3}{c|}{ Hasil Belajar } \\
\cline { 2 - 4 } & Pra Siklus & Siklus I & Siklus II \\
\hline Jumlah Siswa & 43 & 43 & 43 \\
\hline Jumlah Siswa yang Tuntas & 17 & 35 & 41 \\
\hline Jumlah Siswa yang Tidak Tuntas & 26 & 8 & 2 \\
\hline Jumlah Nilai & 2780 & 3240 & 3852 \\
\hline Nilai Rata-rata & 64,6 & 75,3 & 89,5 \\
\hline Ketuntasan Belajar Klasikal & $39,5 \%$ & $81,3 \%$ & $97,6 \%$ \\
\hline
\end{tabular}

Berdasarkan Tabel 5, dapat diketahui bahwa hasil belajar kognitif siswa mengtalami peningkatan. Pendekatan konstruktivisme dapat membuat siswa lebih aktif ketika kegiatan pembelajaran, sehingga siswa mudah paham terhadap materi yang diajarkan dan dapat meningkatkan pemahaman matematika siswa. Hal ini dapat dilihat pada pra siklus yaitu jumlah nilai sebesar 2780 dari 43 siswa sehingga didapatkan nilai rata-rata sebesar 64,6 dengan persentase ketuntasan sebesar 39,5\%, hal ini membuktikan bahwa pembelajaran matematika pada pra siklus sebelum menggunakan pendekatan konstruktivisme masih rendah atau dibawah rata-rata.

Pada siklus I setelah menggunakan pendekatan konstruktivisme membuktikan adanya peningkatan pemahaman matematika siswa dengan nilai rata-rata sebesar 75,3 dengan persentase ketuntasan sebesar $81,3 \%$ dan pada siklus II pemahaman matematika siswa lebih meningkat lagi dengan nilai rata-rata sebesar 89,5 dengan persentase ketuntasan sebesar $97,6 \%$. 
Jadi kesimpulan dari penelitian tindakan kelas ini dikatakan sudah berhasil karena terbukti terjadi peningkatan hasil belajar yang signifikan dari setiap siklusnya melebihi dari nilai KKM yaitu 70, sehingga hipotesis tindakan yang diajukan peneliti terjawab dengan simpulan akhir bahwa pendekatan konstruktivisme dapat meningkatkan pemahaman siswa pada mata pelajaran Matematika pokok bahasan pengolahan data di kelas V MIN 1 Kota Bandung.

B. Deskripsi Hasil Observasi Aktivitas Guru dan Siswa

Pengamatan terhadap aktivitas guru dan siswa dilakukan di setiap proses pembelajaran siklus I dan siklus II dengan masing-masing siklus dilaksanakan dua pertemuan. Dengan semikian dilakukan empat kali pengamatan pada masing-masing aktivitas guru dan siswa dalam pembelajaran. Adapun ringkasan analisis hasil pengamatan aktivitas guru dan aktivitas siswa ditunjukan pada tabel 2 .

Tabel 6. Ringkasan Hasil Observasi Aktivitas Guru dan Siswa

\begin{tabular}{|l|c|c|c|c|}
\hline \multirow{2}{*}{ Observasi Aktivitas } & \multicolumn{2}{c|}{ Siklus I } & \multicolumn{2}{c|}{ Siklus II } \\
\cline { 2 - 5 } & Tindakan I & Tindakan II & Tindakan I & Tindakan II \\
\hline Aktivitas Guru & $83,30 \%$ & $83,30 \%$ & $91,60 \%$ & $100 \%$ \\
\hline Aktivitas Siswa & $60,40 \%$ & $68,70 \%$ & $85,40 \%$ & $95,80 \%$ \\
\hline
\end{tabular}

Hasil analisis pada Tabel 6 menunjukan bahwa aktivitas guru dalam menerapkan pendekatan konstruktivisme pada siklus I tindakan I dan tindakan II termasuk dalam kategori baik, meskipun sudah pada kategori baik hal ini tentu belum mencapai pada skor maksimal. Hal ini dikarenakan apersepsi yang masih terbilang sudah biasa, maka memasuki siklus II guru lebih menarik minat siswa agar kegiatan belajar dapat lebih aktif serta sehingga pada siklus II mencapai kategori sangat baik.

Begitupun dengan aktivitas siswa dengan menerapkan pendekatan konstruktivisme pada siklus I tindakan I dan tindakan II termasuk dalam kategori cukup serta siklus II tindakan I dan tindakan II termasuk dalam kategori sangat baik. Hal ini sebagaimana ditunjukan oleh indikator pemahaman dan motivasi di awal pembelajaran, membuat siswa meningkatkan pemahamannya dari nilai sebelumnya pada pra siklus yang dibawah ratarata. Hal ini tidak terlepas dari tindakan yang dilakukan oleh guru selama pembelajaran berlangsung.

\section{Pembahasan}

1. Pra Siklus

Pada pembelajaran matematika materi pengolahan data sebelum menggunakan pendekatan konstruktivisme, pemahaman matematika siswa masih dibawah rata-rata yaitu 70. Hal ini dapat terlihat dari evaluasi siswa yang masih banyak belum tuntas untuk mencapai kriteria ketuntasan individual karena masih mengandalkan kemampuan siswa sebelum menggunakan pendekatan konstruktivisme.

Dengan hasil yang masih jauh dari nilai KKM, hal ini didukung dengan pasifnya aktivitas siswa dan kurangnya keterlibatan siswa dakam kegiatan belajar sehingga membuat hasil belajar menjadi dibawah rata-rata seharusnya. Serta kurangnya penggunaan media pembelajaran dan tidak adanya penerapakan metode atau pendekatan atau strategi dalam kegiatan belajar siswa, maka mengakibatkan siswa menjadi pasif dan tidak termotivasi.

Sesuai dengan pendapat yang dikemukakan oleh Rahman dkk (2017: 43) media pembelajaran dan metode dapat lebih meningkatkan motivasi belajar siswa dan bahkan mempengaruhi psikologis terhadap siswa. Maka, dengan penerapan 
pendekatan konstruktivisme diharapkan dapat meningkatkan kemampuan pemahaman matematika siswa.

\section{Proses Pembelajaran Matematika dengan Menerapkan Pendekatan \\ Konstruktivisme}

Pada pembelajaran matematika selama menggunakan pendekatan konstruktivisme, aktivitas siswa dan aktivitas guru menunjukan hasil yang cukup baik hingga sangat baik. Hal ini dapat dibuktikan oleh skor yang didapatkan dari keseluruhan aktivitas pembelajaran matematika dari siklus I dan siklus II. Dengan menerapkan konstruktivisme sebagai pendekatan, siswa cenderung lebih aktif dalam mengikuti proses pembelajaran dari awal hingga akhir dan guru lebih semangat dalam memberikan pelajaran.

Hal ini sesuai dengan pendapat Azmi (2014: 131) bahwa dengan pendekatan konstruktivisme, pembelajaran dapat lebih menekankan pengajaran yang top down dari pada bottom up, dengan arti siswa bias memulai masalah lebih kompleks untuk dipecahkan kemudian ditemukan. Maka penerapan pendekatan konstruktivisme dianggap berhasil dalam pembelajaran di siklus I dan II.

3. Hasil Peningkatan Pembelajaran Siswa dengan Menerapkan Pendekatan Konstruktivisme

Terdapatnya perbedaan peningkatan pemahaman konsep matematika siswa antara sebelum menggunakan pendekatan konstruktivisme dengan setelah menggunakan pendekatan konstruktivisme, karena kegiatan dalam proses pembelajaran yang dilakukan pada pra siklus, siklus I dan siklus II sangatlah berbeda.

Seperti yang diungkapkan oleh Syahbana (2012: 52) bahwa proses mengkonstruksi pengetahuan perlu adanya keterkaitan antara apa yang dipelajari dengan konsep yang dituju, salah satunya matematika yaitu dengan pengalaman sendiri. Dengan pengalaman, maka didapatkan makna sehingga makna tersebut memberikan alasan untuk belajar dan membuat pengetahuannya menjadi meningkat dari pengetahuan sebelumnya.

Berdasarkan hasil tes pemahaman konsep pada siswa yang memperoleh dengan pendekatan konstruktivisme. Dengan demikian pada pembelajaran dengan menggunakan pendekatan knstruktivisme berpengaruh secara signifikan pada kemampuan pemahaman matematika siswa.

\section{KESIMPULAN}

Berdasarkan hasil analisis data tentang upaya meningkatkan pemahaman siswa dalam pembelajaran matematika melalui penerapan pendekatan konstruktivisme pada siswa kelas V MIN 1 Kota Bandung dapat disimpulkan yaitu: 1) Pemahaman siswa kelas V MIN 1 Kota Bandung pokok bahasan pengolahan data sebelum menerapkan pendekatan konstruktivisme masih kurang atau banyak yang belum tuntas, karena masih banyak siswa yang nilai mata pelajaran matematika dibawah KKM. Hal ini dibuktikan dengan hasil pre test berupa soal uraian sebanyak lima butir soal, dari 43 orang siswa kelas V nilai rata-ratanya 64,6 dengan kriteria cukup karena berada pada rentang 60-69 dengan ketuntasan belajar hanya mencapai 39,5\% sebanyak 17 siswa telah tuntas belajarnya, dan sebanyak $26(60,5 \%)$ siswa belum tuntas belajarnya disebabkan belum mendapatkan nilai sesuai dengan KKM yaitu 70. 2) Gambaran proses penerapan pendekatan konstruktivisme pada pembelajaran matematika pokok bahasan pengolahan data dilihat dari aktivitas guru dan siswa pada siklus I dan II mengalami peningkatan yang signifikan. Pada siklus I tindakan I persentase aktivitas guru mencapai $83,3 \%$ dan siklus I tindakan II persentase aktivitas guru mencapai $83,3 \%$ keduanya memiliki skor yang sama sehingga masuk ke dalam kategori baik. 
Pada siklus II tindakan I persentase aktivitas guru mencapai 91,6\% dan siklus II tindakan II persentase aktivitas guru mencapai $100 \%$, keduanya memiliki kriteria yang sama yaitu sangat baik. Persentase rata-rata aktivitas siswa pada siklus I tindakan I mencapai $60,4 \%$ dan siklus I tindakan II persentase aktivitas siswa mencapai $68,7 \%$ keduanya termasuk dalam kategori cukup. Pada siklus II tindakan I persenatse aktivitas siswa mencapai $85,4 \%$ dan pada siklus II tindakan II persentase aktivitas siswa mengalami peningkatan yang signifikan yaitu mencapai 95,8\% termasuk ke dalam kategori baik sekali. 3) Peningkatan pemahaman matematika siswa pada kelas V MIN 1 Kota Bandung pokok bahasan pengolahan data dengan menerapkan pendekatan konstruktivisme mengalami peningkatan yang signifikan dari siklus I ke Siklus II. Pada siklus I nilai rata-rata klasikal matematika kelas $\mathrm{V}$ adalah 75,3 dengan kriteria baik karena berada pada interval 70-79 dengan persentase ketuntasan belajar klasikal sebesar $81,3 \%$. Sedangkan pada siklus II nilai ratarata klasikal matematika kelas $\mathrm{V}$ adalah 89,5 dengan kriteria sangat baik karena berada pada interval 80-100 dengan persentase ketuntasan belajar klasikal sebesar 97,6\%. Berdasarkan hasil yang diperoleh, maka terbukti bahwa pendekatan konstruktivisme dapat meningkatkan pemahaman siswa pada mata pelajaran matematika pokok bahasan pengolahan data.

\section{DAFTAR PUSTAKA}

Arikunto, dkk. (2009). Penelitian Tindakan Kelas. Jakarta. PT Bumi Aksara

Azmi, SRM. (2015). Penerapan Pendekatan Konstruktivisme Dengan Model Pembelajaran Kooperatif Tipe Numbered Heads Together (NHT) Untuk Meningkatkan Aktivitas Belajar Sains Siswa Di Kelas V SD Negeri 010145 Labuhan $\begin{array}{lll}\text { Ruku T.P 2103/2014. } & \text { T.P }\end{array}$ http://jurnatik.amikroyal.ac.id/index.php/amikroyal/article/view/30

Bhattacharjee, Jayeeta. (2015). Constructivist Approach to Learning An Effective of Teaching Learning. http://www.irjims.com

Diaz, LDE. (2017). The Teaching and Learning Process of Mathematics in the Primary Education Stage: a Constructivist Proposal within the Framework of Key Competences. http://www.iejme.com

Dwijayanti, Ida. (2011). Pengembangan Perangkat Pembelajaran Matematika Humanistik Berbasis Konstruktivisme Menggunakan ICT Materi Segi Empat Kelas VII. http://journal.upgris.ac.id/index.php/aksioma/article/view/34

Gupita ,Puti Nurma. (2016). Upaya Meningkatkan Pemahaman Siswa Dalam Pembelajaran Ipa Pokok Bahasan Energi Bunyi Melalui Penerapan Metode Eksperimen.

Rahman, dkk. (2017). Media Pembelajaran IPA Kelas 3 Sekolah Dasar Menggunakan Teknologi Augmented Reality Berbasis Android. http://ojs.amikomj.ac.id/index.php/semnasteknomedia/article/view/1797

Sabil, Husni. (2012). Efektifitas Tes Formatif Pada Pembelajaran Matematika di SMPN 16 Kota Jambi. http://ejournal.uns.ac.id/index.php/article/556

Setyawan, Dedy dan Rahman, Abdul. (2013). Eksplorasi Proses Konstruksi Pengetahuan Matematika Berdasarkan Gaya Berpikir. http://ojs.unm.ac.id/index.php/sainsmat

Syahbana, Ali. (2012) Penilaian Keampuan Berpikir Kritis Matematis Siswa SMP Melalui Pendekatan Contextual Teaching and Learning. http://onlinejournal.unja.ac.id/index.php//edumatica/article/view/604

Wiriatmadja, Rochiati. (2012). Metode Penelitian Tindakan Kelas. Bandung: PT Remaja Rosdakarya 